\title{
PEELING THE ORANGE: A CRITICAL ASSESSMENT OF THE LEGALITY OF THE EUROPEAN UNION SANITARY AND PHYTOSANITARY MEASURES REGIME AGAINST CITRUS PRODUCE FROM SOUTH AFRICA
}

\author{
Clive Vinti \\ LLB LLM \\ Lecturer, Public Law \\ University of the Free State \\ Loyiso Makapela \\ LLB LLM \\ PhD Candidate, Stellenbosch University and \\ Vrije Universiteit, Amsterdam
}

\section{SUMMARY}

This article examines the legality of the European Union's sanitary and phytosanitary (SPS) regime implemented against citrus produce from South Africa. In essence, South Africa contends that the European Union's SPS measures lack a technical and scientific basis in violation of the Agreement on the Application of Sanitary and Phytosanitary Measures. It is clear from the Pest Risk Assessments discussed in this article, in accordance with the requirements of the relevant articles of the Agreement on the Application of Sanitary and Phytosanitary Measures, that the likelihood of Citrus Black Spot establishing itself and spreading in the European Union is miniscule. This article concludes that the European Union SPS regime is neither based on sufficient scientific evidence nor scientific certainty; rather, it is based on speculation and conjecture, both of which are never grounds for establishing an appropriate level of protection.

\section{INTRODUCTION}

The European Union has through Council Directive 2000/29/EC and Commission Implementing Decision 2014/422/EU, created sanitary and phytosanitary measures (SPS) to prevent the entry, establishment and spread into the European Union of organisms harmful to plants or plant products originating from South Africa. South Africa is the second largest 
citrus exporter in the world and exports $40 \%$ of citrus fruit to the European Union. ${ }^{1}$ However, South Africa's citrus produce is susceptible to citrus black spot (CBS). CBS is a fungal fruit disease that causes superficial lesions on fruit but is harmless to humans. South Africa has developed the CBS Risk Management System to prevent the spread of CBS to the EU.

Despite all these efforts, South Africa has repeatedly fallen foul of the Council Directives, and is in danger of a total ban of its citrus produce to the Europe Union (EU). Consequently, the Citrus Growers Association (CGA), has decided to halt organic lemon exports to the EU for the 2016 season. The CGA represents the interests of the producers of export citrus, and approximately represents 1400 growers throughout Southern Africa, including Zimbabwe and Swaziland. ${ }^{3}$

South Africa contends that the European Union's SPS measures lack a technical and scientific basis, and that infested fruit does not pose a significant pest risk. ${ }^{4}$ In essence, SA contends that the EU SPS regime merely constitutes disguised discrimination and protectionism.

Therefore, the objective of this article is to suggest the legal grounds for a challenge of the SPS measures employed by the European Union. The first part explains the salient features of CBS. The object here is to clearly enunciate the specific features and the legal issues that emanate therefrom. This will involve a study of the various pest-risk assessment studies conducted by international experts in the field of CBS.

The second part of this article traces the genesis of the dispute. This will entail a chronological exposition of the measures employed by the EU to curb CBS, and the institutional responses to the EU measures and methods employed by South Africa to address the problem of CBS.

The final part of this article assesses the legality of the SPS measures targeting South African citrus produce against the legal framework of the WTO. The article ends with some concluding remarks.

Consequently, the first legal issue that is investigated is whether the EU SPS measures are supported by legitimate science. Secondly, whether there is a scientific basis for the EU SPS regime, and the attendant legal issue of whether there is a rational link between the EU SPS regime and the science informing it; thirdly, whether the measures are aimed at disguised discrimination. The fourth legal issue that emanates is whether the EU SPS regime seeks to minimize trade effects. Fifthly, there will be an assessment of whether the EU SPS measures are necessary to preserve human and

European Commission Directorate General for Health and Food Safety "Final Report of an audit carried out in South Africa from 24 February 2015 to 06 March 2015 in order to evaluate the system of official controls and the certification of citrus fruit for export to the European Union" 7 August 2015 ec.europa.eu (hereinafter "the Final Report") (accessed 2016-07-16) 6.

2 Du Preez "Organic Citrus Farmers Voluntarily Halt Lemon Exports to the EU" 22 April 2016 Farmer's Weekly; and Magwaza "SA's Citrus Growers Voluntarily Halt Lemon Exports to EU" 7 April 2016 Business Day.

3 Citrus Growers Association "CGA Promotional Brochure" (undated) www.cga.co.za (accessed 2016-05-23) 4.

4 WTO Committee on Sanitary and Phytosanitary Measures "Specific Trade Concerns" 23 February 2016 www.wto.org (accessed 2016-05-22) 60. 
plant life, and whether the measures are not more trade-restrictive than necessary. The final legal issue is whether the EU SPS regime takes into account the special needs of developing countries.

\section{THE SALIENT FEATURES OF CITRUS BLACK SPOT}

CBS is caused by the fungus Guignardia citricarpa Kiely anamorph Phyllosticta citricarpa (McAlpine) van der Ai which is a fruit disease of citrus that causes superficial lesions on fruit, leaf spotting and fruit blemishes, but is harmless to humans and is most commonly found in lemons and Valencia oranges. ${ }^{5}$ Thus Phyllosticta citricarpa is the causative agent of citrus black spot. $^{6}$ Lemons are most susceptible. ${ }^{7}$ The CBS fungus is not present in the $\mathrm{EU}$ and is identified by the EU as a fungus whose introduction and spread within the EU is banned. ${ }^{8}$ The first known discovery of CBS was made in New South Wales in Australia in the year 1895, with the first case recorded in South Africa in $1929 .{ }^{9}$ The disease has been recorded in other countries as well, namely: Argentina, Brazil, Indonesia, India, the Philippines, Venezuela, Zimbabwe, and China. ${ }^{10}$ However, the disease has not been documented in countries such as Greece, Turkey, Portugal, Italy, France and Spain, all of which are citrus-producing areas in Europe and the Mediterranean. ${ }^{11}$ Essentially, CBS is not known to occur in the EU, but is present in various tropical and sub-tropical citrus-growing regions, such as South Africa.

\section{THE GENESIS OF THE CITRUS DISPUTE}

\section{The EU law on SPS measures}

Council Directive 2000/29/EC of 8 May $2000^{13}$ provides protective measures against the introduction into the Member States from other Member States or third countries of organisms which are harmful to plants or plant products. ${ }^{14} \mathrm{CDI} 2000$ lists CBS as a harmful organism whose introduction into and spread into the EU is banned. ${ }^{15}$ The EU then decided on the basis of the European Food Safety Authority (EFSA) CBS Pest Risk Assessment of 2014, and the high number of recurring CBS interceptions in the previous

5 CDI 2000 Annex II Part A section 1(c). See EFSA "Pest risk assessment and additional evidence provided by South Africa on Guignardia citricarpa Kiely, citrus black spot fungus CBS1 :Scientific Opinion of the Panel on Plant Health" 2008925 EFSA Journal 10-108.

6 Final Report http://ec.europa.eu/food/fvo/audit_reports/details.cfm?rep_id=3483 2.

7 Kotze "Epidemiology and Control of Citrus Black Spot in South Africa" 1981 Plant Disease 945945.

8 Final Report http://ec.europa.eu/food/fvo/audit_reports/details.cfm?rep_id=3483 2.

9 EFSA 2008925 EFSA Journal 11-108.

10 Hatting et al "Pest Risk Assessment document for the review of current phytosanitary regulations pertaining to the export of fresh Citrus fruit from the Republic of South Africa to the EU" May 2000 http://www.citrusres.com/ 2.

11 EFSA 2008925 EFSA Journal 11-108.

12 EFSA 2015 EFSA Journal 4.

13 Hereinafter "CDI 2000".

14 Article 1 of CDI 2000.

15 CID 2000 ANNEX II Part A s 1(c) 11. 
years from citrus fruit originating in South Africa, to introduce stricter measures through the Commission Implementing Decision 2014/422/EU of 2 July $2014 .^{16}$

However, prior to CID 2014, the European Commission Standing Committee on Plant Health had implemented stricter requirements, against SA citrus produce requiring inter alia, that a sample of at least 600 of each type of citrus fruit per 30 tonnes will need to be taken by the South African authorities, and that all fruit showing symptoms would be tested and a sample per 30 tonnes of Citrus sinensis (L.) Osbeck "Valencia" would also be tested. ${ }^{17}$ Consequently, the measures in CID 2014 are in accordance with the opinion of the Standing Committee on Plant Health. ${ }^{18}$

CID 2014 specifically sets out measures in respect of certain citrus fruits originating in South Africa to prevent the introduction and spread within the Union of Phyllosticta citricarpa (CBS).$^{19}$ These include additional checks and traceability requirements for all citrus fruit not produced within an area, officially recognized by the EU as being free from CBS. ${ }^{20}$ It also provides that, if the presence of CBS is confirmed, the batch from which the sample has been taken shall be prohibited from entering EU or destruction, other than by processing. ${ }^{21}$ The CID 2014 is based on the findings of the European Food Safety Authority Pest Risk Assessment published on 21 February 2014 which concluded that CBS is a threat to the EU and the need to implement stricter requirements after the high recurring CBS interceptions form citrus produce originating from South Africa. ${ }^{22}$ Thus the main object of these two directives is to prohibit the entry, establishment and spread of CBS into the EU.

The CGA regards the CID 2014 as a qualified success as it was drafted on the basis of two scientific papers submitted by South Africa: an analysis of CBS interception history and known science to test for CBS submitted by South Africa. ${ }^{23}$ South Africa believes that the new regime created by CDI 2014 is academically sound and is a manageable process as compared to the strict regime created by $\mathrm{CDI} 2000$, and the stringent measures introduced by the European Commission Standing Committee on Plant Health. ${ }^{24}$

However, European Union Member States notified a total of 279 interceptions concerning citrus fruits exported from South Africa between 2011 and 2014, in EUROPHYT, the EU's notification system for plant

16 Hereinafter "CID 2014" preamble par 2.

17 EU "European Commission Standing Committee on Plant Health Summary Report of the Standing Committee on Plant Health" 27 May 2014 www.ec.europa.eu (accessed 2016-0327) 3.

18 CID preamble par 7.

19 Final Report http://ec.europa.eu/food/fvo/audit_reports/details.cfm?rep_id=3483 2.

20 Ibid.

21 CID 2014 Annex: Requirements for introduction of the specified fruits referred to in Article 1 par 2.2.

22 CID 2014 preamble par 2.

23 CGA "Citrus Growers Annual Report 2015" (undated) www.cga.co.za (accessed 2016-0326) 18.

24 lbid. 
health. ${ }^{25}$ One hundred and seventy three of these notifications were of interceptions due to the presence of harmful organisms. ${ }^{26}$ The remaining one hundred and six were due mainly to incomplete additional declarations on phytosanitary certificates accompanying the consignments. ${ }^{27}$ Phytosanitary certificates are issued to indicate that consignments of plants, plant products or/and other regulated articles comply with the specified phytosanitary import requirements of the National Plant Protection Organisation (NPPO) of the importing country, and are in conformity with the certifying statement on the phytosanitary certificate. ${ }^{28}$ The most commonly intercepted harmful organism during the four-year period was CBS, accounting for one hundred and twenty nine interceptions.

\section{South Africa's response}

Prior to the advent of the Agreement on the Application of Sanitary and Phytosanitary Measures (SPS) and the International Plant Protection Convention (IPPC), South Africa had promulgated the Agricultural Pests Act 36 of 1983 to deal with national phytosanitary measures. However, the Agricultural Pests Act is deficient in certain respects as it was promulgated before the advent of the IPPC and the SPS agreement: for instance, it does not provide for the establishment and responsibilities of the national plantprotection contact point; the establishment and declaration of pest-free areas and export control of plants and plant products. ${ }^{30}$

As a result of the long-standing citrus black-spot dispute with the EU, spanning almost two decades at the time, South Africa requested the IPPC in 2010 to intervene. ${ }^{31}$ In 2012, the EU announced their intention to institute a five-interception cut-off point for CBS in citrus consignments from SA during the 2013 season. ${ }^{32}$ Subsequent to the pronouncement of the stringent measures, SA instituted a revised CBS risk-management system.

South Africa created the national phytosanitary regulatory system which includes Department of Agriculture, Forestry and Fisheries (DAFF) directorates Plant Health (DPH): policy unit, Inspection Services (DIS) and Food Import and Export Standards (DFIES): operational units, as well as the

25 Final Report http://ec.europa.eu/food/fvo/audit_reports/details.cfm?rep_id=3483 4 .

26 Final Report http://ec.europa.eu/food/fvo/audit_reports/details.cfm?rep_id=3483 4.

27 Ibid.

28 Department of Agriculture, Forestry and Fisheries "Guideline for completion of phytosanitary certificates for/by client" 3 June 2009 http://www.nda.agric.za/doaDev/sideMenu/APIS/doc/ Guideline\%20for\%20completion\%20if\%20phytosanitary\%20certificates\%20(5).pdf (accessed 2016-03-27).

29 Final Report http://ec.europa.eu/food/fvo/audit_reports/details.cfm?rep_id=3483 4.

30 GN 889 in GG 38102 of 2014-10-17 (Plant Health [Phytosanitary] Policy for South Africa) 13

31 CGA "Grower Advisory: Citrus Black Spot and the EU" 24 January 2013 www.cga.co.za (accessed 2016-05-23). See Magwaza "UN body to pick expert panel on citrus black spot" 29 September 2014 www.iol.co.za (accessed 2016-02-27). See also WTO Committee on Sanitary and Phytosanitary Measures "Specific Trade Concerns" 23 February 2016 www.wto.org (accessed 2016-07-23) 61.

32 DAFF "DAFF Media Statement: Status of the Citrus Phytosanitary Measures relating to the European Union" 7 August 2013 www.daff.gov.za (accessed 2016-06-27) 1. 
Perishable Products Export Control Board (PPECB). ${ }^{33}$ The DPH and DIS, together with the DFIES, serve as the National Plant Protection Organization of South Africa (NPPOZA). ${ }^{34}$ The main purpose of the NPPOZA is to maintain a database on the import conditions and procedures of various countries and the occurrence of harmful organisms in South Africa. ${ }^{35}$

Recently, and more specifically to citrus produce, the DAFF in South Africa has created the CBS Risk Management Scheme (CBS-RMS) in consultation with the Perishable Products Export Control Board and stakeholders, to provide a mechanism to control the risk of CBS being present on fruits of citrus exported to the EU, and ensure compliance with EU import requirements for such fruit. ${ }^{36}$ The CBS-RMS specifies the roles and responsibilities of various stakeholders, as well as the procedures to be followed, and the official checks to be carried out prior to the export of citrus fruits. ${ }^{37}$ Only fruit that is produced and handled in accordance with the scheme may be exported to the EU. ${ }^{38}$ As a signatory member of both the IPPC and WTO-SPS Agreement, South Africa is obliged to apply harmonized standards in order to facilitate safe, fair and free trade. ${ }^{39}$ South Africa, therefore, applies the principles set out in the International Plant Protection Convention's International Standards for Phytosanitary Measures (ISPMs) which aim to harmonize phytosanitary measures. ${ }^{40}$ These principles are also applied on a regional level, where the Southern African Development Community (SADC) Protocol on Trade constitutes the framework for cooperation in sanitary and phytosanitary matters. ${ }^{41}$ However, the current legislation does not mandate the existence and function of the NPPOZA as per Article IV of the IPPC. ${ }^{42}$ The CBS-RMS has been extensively revised since 2009, in light of experience gained during each subsequent export season and the outcome of investigations, following findings of non-compliance or EU interceptions of Phyllosticta citricarpa. ${ }^{43}$ The version in force at the time of the latest audit of the EU was issued on 15 January $2015 .{ }^{44}$ As a result of these initiatives, the South African citrus industry has made great strides in reducing detections of CBS from 35 in 2013, to 28 in 2014 and 15 in 2015 according to the CGA. ${ }^{45}$ It is estimated

\footnotetext{
GN 889 in GG 38102 of 2014-10-17 20.

GN 889 in GG 38102 of 2014-10-17 13.

35 DAFF "The South African Emergency Plant Pest Response Plan: General guidelines for rapid response and effective control of emergency plant pests" 1 January 2013 www.plantsa.co.za (accessed 2016-06-27).

Final Report http://ec.europa.eu/food/fvo/audit_reports/details.cfm?rep_id=3483 7.

Ibid.

38 Final Report http://ec.europa.eu/food/fvo/audit_reports/details.cfm?rep_id=3483 4.

39 GN 889 in GG 38102 of 2014-10-17 12.

40 Ibid.

Article 16 of SADC Protocol on Trade.

2 GN 889 in GG 38102 of 2014-10-17 13.

43 Final Report http://ec.europa.eu/food/fvo/audit_reports/details.cfm?rep_id=3483 7.

44 Ibid.

45 Du Preez "Organic Citrus Farmers Voluntarily Halt Lemon Exports to the EU" 22 April 2016 Farmer's Weekly.
} 
that the South African citrus value chain spent an additional R1 billion on EU exports as a result of the CBS issue. ${ }^{46}$

At the request of South Africa, the IPPC Secretariat then hosted a formal consultation between South Africa and the European Union under the IPPC Dispute Settlement System (DSS), on 26 February 2013 which dealt with the SPS dispute on Citrus Black Spot. ${ }^{47}$ Then in June 2013, SA notified the WTO SPS Committee about its concerns regarding the EU restrictive import measures on South African citrus exports infested with citrus black spot. ${ }^{48}$ The SPS Committee is a platform for WTO members to exchange information on all aspects of the implementation of the SPS, and permits members to request the assistance of the Chair to help resolve specific trade concerns (STCs) raised by WTO Members. ${ }^{49}$

After the EFSA 2014 PRA which found that CBS was a risk to the EU, the European Commission Standing Committee on Plant Health then decided on additional import measures for citrus fruit from South Africa, which had taken effect in July $2014 .^{50}$ Consequently South Africa voluntarily suspended exports from certain areas for the rest of 2014, and then requested the IPPC secretariat to establish an expert committee in line with Article XIII of the IPPC to provide an independent science-based opinion. ${ }^{51}$ Article XIII of the IPCC provides that contracting parties to the agreement, in respect to any action by a contracting party prohibiting or restricting of plants or plant products, may request consultations among themselves and, if that fails, they may request the Secretary General of the Food and Agricultural Organization to appoint a committee of experts who will compile a technical report with the purpose of seeking a relevant resolution.

In July 2015, South Africa reiterated its concerns to the WTO Committee on Sanitary and Phytosanitary Measures, on EU restrictive import requirements regarding citrus fruit. ${ }^{52}$ South Africa then urged the IPPC to expedite the process. ${ }^{53}$ This is the first formal dispute under the IPPC dispute-resolution mechanism. ${ }^{54}$ However, the IPPC has endured significant difficulties in finding neutral scientific experts on CBS, and has expanded its search by including experts in the area of risk assessment as it is related to CBS. ${ }^{55}$ In October 2015, South Africa reiterated its concerns regarding

46 CGA "Annual Report of the Citrus Growers Association of Southern Africa 2015" www.cga.co.za (accessed 2016-03-25) 4.

47 IPPC "The IPPC Dispute Settlement System: consultation between EU and SA" 23 April 2013 www.ippc.int (accessed 2016-02-16).

48 WTO Committee on Sanitary and Phytosanitary Measures "Specific Trade Concerns" 23 February 2016 www.wto.org (accessed 2016-04-16) 59.

49 WTO Committee on Sanitary and Phytosanitary Measures "Sanitary and phytosanitary measures: Ensuring safe trading without unnecessary restrictions" (undated) www. wto.org/sps (accessed 2016-04-16).

50 WTO Committee on Sanitary and Phytosanitary Measures "Specific Trade Concerns" 23 February 2016 www.wto.org (accessed 2016-03-16) 60.

51 Ibid. See IPPC "Establishment of an IPPC Dispute Settlement Expert Committee: Call for Experts" 25 September 2014 www.ipc.inti (accessed 2016-03-17).

52 WTO Secretariat "Activities of the SPS Committee and other relevant WTO Activities in 2015" 1 March 2016 www.wto.org (accessed 2016-03-27) 6.

53 lbid.

54 lbid.

55 Ibid. 
restrictive EU import requirements on citrus fruit. ${ }^{56}$ Brazil and Zambia shared South Africa's concern, and Brazil offered assistance to expedite the IPPC process so that it could be concluded with the necessary urgency. ${ }^{57}$

The EU's 2015 audit of SA's system of official controls and the certification of citrus fruit for export to the European Union has found that the NPPO in South Africa has significantly strengthened its export procedures and system of official checks. ${ }^{58}$ The objective of the audit was to evaluate the system of official plant-health controls and the certification of citrus fruit for export to the European Union, according to the requirements of Council Directive 2000/29/EC and Commission Implementing Decision 2014/422/EU. ${ }^{59}$ In terms of scope, the audit evaluated the implementation of the South African CBS Risk Management System for Citrus fruits exported to the EU. ${ }^{60}$ However, the EU audit has found that it is unclear whether the citrus fruit exported to the EU is free from CBS. ${ }^{61}$ Consequently, the CGA has decided to halt organic lemon exports to the EU for the 2016 season. ${ }^{62}$ This is because the lemon is considered to be the citrus species that is most susceptible to CBS, and it has been stated that the first disease outbreaks in a region always occurred in lemon orchards and later spread to adjacent citrus orchards. ${ }^{63}$ As a result, it is estimated that losses of 50 million rand will hit the South African organic citrus growers. ${ }^{64}$

\section{ASSESSING THE LEGALITY OF THE EU SPS MEASURES IN LIGHT OF THE WTO FRAMEWORK}

\section{The World Trade Organization rules regulating sanitary and phytosanitary measures}

The Agreement on the Application of Sanitary and Phytosanitary Measures (SPS) is the constitutive text of the WTO that sets out the requirements for all sanitary and phytosanitary measures which may, directly or indirectly, affect international trade. ${ }^{65}$ Such measures include that inter alia all relevant laws, decrees, regulations, requirements and procedures, shall be developed and applied in accordance with the provisions of this Agreement. ${ }^{66}$ SPS measures are defined as any measure applied to: protect

\footnotetext{
WTO Secretariat "Activities of the SPS Committee and other relevant WTO Activities in 2015" 1 March 2016 www.wto.org (accessed 2016-03-27) 6.

57 Ibid.

58 Final Report http://ec.europa.eu/food/fvo/audit_reports/details.cfm?rep_id=3483 28.

59 Final Report http://ec.europa.eu/food/fvo/audit_reports/details.cfm?rep_id=3483 1.

Ibid.

1 Final Report http://ec.europa.eu/food/fvo/audit_reports/details.cfm?rep_id=348328.

62 Du Preez "Organic Citrus Farmers Voluntarily Halt Lemon Exports to the EU" 22 April 2016 Farmer's Weekly.

63 EFSA Panel on Plant Health (PLH) 2014 "Scientific Opinion on the risk of Phyllosticta citricarpa (Guignardia Citricarpa) for the EU territory with identification and evaluation of risk reduction options" 2014 12(2) EFSA Journal 355722.

64 Du Preez "Organic Citrus Farmers Voluntarily Halt Lemon Exports to the EU" 22 April 2016 Farmer's Weekly.

65 Article 1.1 of the SPS read with Annex A (1) of the SPS.

66 Ibid.
} 
human or animal life from risks arising from additives, contaminants, toxins or disease-causing organisms in their food; protect human life from plant- or animal-carried diseases; protect animal or plant life from pests, diseasecausing organisms; and prevent or limit other damage to a country from the entry, establishment or spread of pests. ${ }^{67}$

Secondly, Article 2.2 of the SPS provides that members shall ensure that any sanitary or phytosanitary measure is applied only to the extent necessary to protect human, animal or plant life or health, is based on scientific principles and is not maintained without sufficient scientific evidence, except as provided for in paragraph 7 of Article 5 . In the same vein, Article 5.1 of the SPS essentially provides that members shall ensure that their sanitary or phytosanitary measures are based on an appropriate pest-risk assessment (PRA). Thus Article 2.2 and 5.1 must always be read together. This is because the provisions of Article 5 specifically elaborate on the basic rights and obligations in Article 2.2. The structure and logic of the SPS, as understood in the light of the relationship between the various provisions of Articles 5 and 2, is such that the appropriate method for complying with the basic obligations under Article 2 is through the specific avenue of Article $5{ }^{68}$ Thirdly, members are required to ensure that their sanitary and phytosanitary measures do not arbitrarily or unjustifiably discriminate between members where identical or similar conditions prevail, including between their own territory and that of other members. ${ }^{69}$ Fourthly, sanitary and phytosanitary measures should not be applied in a manner which would constitute a disguised restriction on international trade. ${ }^{70}$ The discussion to follow assesses the legal validity of the SPS measures created by CDI 2000 and CID 2014 within the parameters of the rules enunciated above.

\section{The grounds available to SA for a challenge of the EU SPS measures}

The preliminary issue in the discussion is whether the measures in question constitute an SPS measure within the parameters of Article 1 and Annex $\mathrm{A}(1)$ of the SPS. The Panel in EC-Hormones held that in order for a measure to come within the scope of the SPS, two requirements must be fulfilled: Firstly, the measure must be an SPS measure and secondly, it must be measure that may directly or indirectly affect trade. ${ }^{71}$ In this regard, the CDI 2000 and CID 2014 provide legislative protective measures against the

67 Annex A (1) of the SPS.

68 Appellate Body Report, Australia - Measures affecting the importation of Apples from New Zealand (from here on Australia Apples) WT/DS367/AB/R par 339. See further Panel Report, Australia -Measures Affecting the importation of Salmon WT/DS18/R (Australia Salmon) par 8.52

69 Article 2.3 of the SPS

70 lbid.

71 Article 1.1 of the SPS. See further Panel Report EC Measures Concerning Meat and Meat Products (Hormones) WT/DS26/R/USA par 8.36. See also Van Den Bossche The Law and Policy of the World Trade Organization: Texts, Cases and Materials 2ed (2010) 837,in which he opines that the requirement that the measure must be one that may directly or indirectly affect trade is easy to fulfil because any measure that applies to imports can be said to affect international trade. 
introduction into the EU of certain citrus fruits originating in South Africa, infected with Citrus Black Spot. Secondly, it is clear that both instruments constitute SPS measures within the definition of Article 1.1 and Annex A(1) of the SPS, as they seek to protect human and plant life from pests or disease-causing organisms, in this case CBS, and to prevent the entry, establishment and spread of CBS in the EU. There is no doubt that the measures affect trade because they have led to SA banning lemon exports to the EU for the 2016 harvest season, and the EU has instituted bans on SA citrus in the past, resulting in huge financial losses. Thus it has been established that the measures in question constitute SPS measures within the definition of the SPS Agreement. These considerations guide and permeate the discussion that follows.

\section{Ground 1: Whether the SPS measure is based on} scientific principles, and is not maintained without sufficient scientific evidence, except as provided for in paragraph 7 of article $5 .^{72}$

(a) That the evidence derives from a "legitimate source" and is considered "legitimate science"

Firstly, in Canada - Continued Suspension of obligations in the ECHormones, the Appellate Body (AB) stated that, with respect to the scientific basis underlying an SPS measure, a panel should verify whether it "comes from a respected and qualified source" and has "the necessary scientific and methodological rigour to be considered reputable science", and can accordingly be considered "legitimate science" according to the standards of the relevant scientific community. ${ }^{73}$ In this regard, the Pest Risk Assessment (PRA) for the CDI 2000 and the CID 2014 were conducted by the European Food Safety Authority (EFSA), and would fulfil the first requirement that the risk assessment be conducted by a respected and qualified source. This is because the EFSA is a European agency created under the General Food Law - Regulation 178/2002, funded by the European Union that operates independently of the European legislative and executive institutions and EU Member States. ${ }^{74}$ The General Food Law created a European food-safety system in which the EFSA is responsible for the risk-assessment science and has a duty to communicate its scientific findings to the public. ${ }^{75}$

However, SA contends that the EFSA PRA of 2014 reflected a lack of impartial objectivity and suggests a systematic failure of the EFSA PRA process in that EFSA appears to have been biased towards defending an existing position rather than conducting an unbiased, objective assessment

Article 2.2 of the SPS.

73 Appellate Body Report, Canada - Continued Suspension of obligations in the ECHormones WT/DS321/AB/R dispute (Canada Suspension) par 591.

74 Article 22 Regulation (EC) No 178/2002 of the European Parliament and of the Council of 28 January 2002.

75 European Food Safety Authority "About EFSA" (undated) www.efsa.europa.eu (accessed 2016-06-23). 
of the available peer-reviewed scientific evidence pertaining to the risk potential. ${ }^{76}$ Thus SA questions the legitimacy of the EFSA and the quality of the science employed therein. The CGA has gone as far as to allege that the EFSA 2008 PRA panel was lacking in expertise in CBS. ${ }^{77}$

\section{(b) That there is sufficient scientific basis for CDI 2000 and} CID 2014

Secondly, in reviewing a risk assessment under Article 5.1 of the SPS, there must be an assessment of whether the reasoning of the risk assessor is objective and coherent and that, therefore, its conclusions find sufficient support in the underlying scientific research. ${ }^{78}$ The AB in Australia Measures affecting the importation of Apples from New Zealand, held that the panel's role was limited to reviewing whether the scientific basis constitutes "legitimate science according to the standards of the relevant scientific community". ${ }^{79}$

The AB has identified Articles 5.1, 3.3, and 5.7 of the SPS Agreement as providing relevant context for interpreting the phrase "maintained without sufficient scientific evidence" in Article 2.2. "Article 3.3 of the SPS essentially provides that members may introduce SPS measures which result in a higher level of sanitary or phytosanitary protection if there is a scientific justification. Operating as a time-based exception, Article 2.2 permits the introduction of an SPS measure provisionally, in instances where relevant scientific evidence is insufficient. Article 5.1 however demands that SPS measures must be based on a risk assessment. In EC-Hormones, the $A B$ clarified that Article 5.1 is a precise application of the basic obligations contained in Article 2.2 of the SPS and that Articles 2.2 and 5.1 should constantly be read together. ${ }^{81}$

The AB has held that the ordinary meaning of "sufficient" is "of a quantity, extent, or scope adequate to a certain purpose or object". ${ }^{82}$ Sufficiency "requires the existence of a sufficient or adequate relationship between two elements, in casu, between the SPS measure and the scientific evidence". ${ }^{83}$ In essence, the conclusions reached in a Pest Risk Assessment (PRA) must be supported by adequate scientific evidence. ${ }^{84}$ To this end, the EU could argue that there is sufficient scientific evidence that the measures employed by SA have not adequately dealt with CBS, as the EU made 15 detections in

76 CBS Expert Panel 2014 "Comments on the European Union Food Safety Authority's Pest Risk Assessment for Phyllosticta citricarpa" August 2014 http://www.citrusres.com (accessed 2016-03-27) 4.

77 CGA “CGA Annual Report 2010” (undated) www.cga.co.za (accessed 2016-04-27) 14.

78 Australia Apples par 220.

79 Australia Apples par 215. See also Canada Suspension par 591.

80 Appellate Body Report, Japan - Measures affecting Agricultural Products WT/DS76/AB/R par 74-80.

81 Australia Apples par 209.

82 Appellate Body Report, Japan - Measures Affecting Agricultural Products WT/DS76/AB/R par 73.

83 Ibid.

84 Canada Suspension par 591. 
2015 according to the CGA. ${ }^{85}$ The European Food Safety Authority has found that living stages of CBS are frequently found on imported citrus fruit during border inspections at the EU points of entry. ${ }^{86}$ The European Food Safety Authority Pest Risk Assessment of 2014 also found that, although the measures employed by SA may reduce the incidence and severity of CBS infection in citrus fruit imported into the EU area, they still fail to completely eliminate the pathogen. ${ }^{87}$ The European Food Safety Authority also rates as likely the probability of association with the pathway at origin for CBS on fresh citrus fruit imported from infested areas into the EU. ${ }^{88}$ Significantly, most EU interceptions of CBS on citrus fruit consignments imported from third countries over the period 1999-2012 originated from Brazil and South Africa. ${ }^{89}$ During 1999-2012, there were 859 interceptions of CBS on citrus fruit consignments from third countries to the EU. ${ }^{90}$ This implies that CBS is associated with the citrus fruit pathway and is able to survive transport and storage as well as existing pest management procedures. ${ }^{91}$ Thus, the EU contends that the number of countries from which interceptions originated provides evidence that citrus fruit can be considered as a major potential pathway of entry for the pathogen. ${ }^{92}$ This supports the conclusion that there is a sufficient scientific basis for the EU SPS regime for SA citrus produce.

Contrary to this assertion, SA contends that the European Food Safety Authority Pest Risk Assessment of 2014 has disregarded scientific evidence indicating the known durability of fruit susceptibility, and has exaggerated the probability of transfer, infection and establishment of CBS in the EU. ${ }^{93}$ SA also argues that the European Food Safety Authority Pest Risk Assessment of 2014 was gleaned from scientific opinion which lacked substantiation, supportive evidence or relevance bar that they were in agreement with a position taken by EFSA, and arrived at conclusions that are unreliable, erroneous and in conflict with strong scientific evidence. ${ }^{94}$ This opinion finds credence with Smyth et al who argue that the EU has in the past proceeded on the basis of selective interpretation of data gathered, as reflected by the EU's decision to maintain its import ban on beef produced using growth hormones, when faced with reports from its own scientific experts that there was no evidence that this product represented a risk. ${ }^{95}$ Kotze also submits that the fact that CBS does not occur under Mediterranean climatic

85 Du Preez "Organic Citrus Farmers Voluntarily Halt Lemon Exports to the EU" 22 April 2016 Farmer's Weekly.

86 EFSA Panel on Plant Health (PLH) 2014 "Scientific Opinion on the risk of Phyllosticta citricarpa (Guignardia Citricarpa) for the EU territory with identification and evaluation of risk reduction options" 2014 12(2) EFSA Journal 355732.

87 EFSA Panel on Plant Health (PLH) 2014 EFSA Journal 35.

88 Ibid.

Ibid.

90 EFSA Panel on Plant Health (PLH) 2014 EFSA Journal 32.

Ibid.

EFSA Panel on Plant Health (PLH) 2014 EFSA Journal 35.

93 CBS Expert Panel 2014 "Comments on the European Union Food Safety Authority's Pest Risk Assessment for Phyllosticta citricarpa" August 2014 http://www.citrusres.com (accessed 2016-7-23) 3.

94 CBS Expert Panel 2014 August 2014 http://www.citrusres.com (accessed 2016-07-23) 4.

95 Smyth et al "Recent Trends in the Scientific Basis of Sanitary and Phytosanitary Trade Rules and Their Potential Impact on Investment" $201112 \mathrm{~J}$ World Investment \& Trade 514. 
conditions, outweighs all hypothetical speculations about possible splash infections during rain and whatever is supposed to follow. ${ }^{96}$ Kotze emphatically submits that, if "fruit" is not a pathway, there is really no rationale for the EU SPS measures. ${ }^{97}$ The CGA explicitly submits that all CBS experts in the world are in agreement that CBS cannot establish in the EU. ${ }^{98}$ Thus SA could argue that the EU SPS measures lack a scientific basis, and are being maintained without sufficient scientific basis. However, SA must be prudent to not pursue the avenue of assessing the correctness of the EU PRAs on CBS, and instead, SA must show that the PRAs are not objectively justifiable in the sense that they are neither supported by coherent reasoning nor respectable scientific evidence.

Furthermore, the determination of "sufficient evidence" hinges on the acceptable standard of review. The standard of review requires a balance between the prerogative of WTO members to set their own acceptable risk levels and compliance with the requirements set down for legitimate measures in the SPS. ${ }^{100}$ The standard of review adopted is an important factor in determining the extent of the role played by scientific experts in SPS dispute settlement. ${ }^{101}$ The role of EFSA is pertinent in this regard because the panels usually rely on the experts to understand and evaluate the scientific arguments put forth. ${ }^{102}$ This places more emphasis on how the experts are selected, consulted and the nature of the questions put to them, as well as issues around the diversity of experts consulted in a dispute, their level of independence and impartiality, and the use made of their expertise in panel decision-making. ${ }^{103}$ On this issue, the SA CBS Expert Panel has criticized the EFSA PRA 2014 expert panel, and alleges that their findings show that the EFSA purports to have more understanding of the research results than the researchers who themselves conducted the research; that the EFSA apparently overlooked the fact that in many cases the authors of the scientific papers were members of the Expert Panel, and that they attached more value to the EFSA's interpretation of the published results than the authors themselves. ${ }^{104}$ These validate SA's contention that the EU SPS measures in question lack a sufficient scientific basis and are not based on legitimate science.

Alternatively, the Appellate Body of the WTO (AB) has observed that responsible and representative governments may act in good faith on the basis of what, at a given time, may be a divergent opinion coming from

96 Kotze "Comments on: "EFSA (2008) Scientific Opinion of the Panel on Plant Health on a request from the European Commission on Guignardia citricarpa Kiely" May 2009 http://www.citrusres.com/ 6.

97 Kotze May 2009 http://www.citrusres.com/ 10.

98 CGA “CGA Annual Report 2010" (undated) www.cga.co.za (accessed 2016-04-24) 16

99 Australia Apples par 213.See further Canada Suspension par 590.

100 Peel "Of Apples and Oranges (And hormones in beef): science and the standard of review in WTO disputes under the SPS agreement" 2012 International and Comparative Law Quarterly 427431.

101 Ibid.

102 Peel 2012 International and Comparative Law Quarterly 432.

103 Ibid.

104 CBS Expert Panel 2014 August 2014 http://www.citrusres.com 3. 
qualified and respected sources. ${ }^{105}$ Thus it is not fatal that the EFSA's opinion differs from prevailing international opinion on CBS. This viewpoint is shared by Smyth et al who argue that the notion of a scientific consensus is a myth and that there will always be a divergent opinion. ${ }^{106}$ In fact, it is submitted by Smyth et al that challenging the conventional wisdom is central to the dynamic of scientific progress. ${ }^{T 7}$ However, SA's CBS Expert Panel of 2014 contends that the EFSA's PRA of 2014 on CBS did not provide reliable evidence to support such alternate views. ${ }^{108}$

In the same vein, the Panel in US-Certain measures affecting imports of poultry from China has added that an approach based on a divergent opinion from a qualified and respected source, does not necessarily imply the absence of a reasonable relationship between the SPS measure and the risk assessment, especially where the risk involved is life-threatening in character and is perceived to constitute a clear and imminent threat to public health and safety. ${ }^{109}$ This decision obviously supports SA's case because CBS is not harmful to humans nor a threat to public health. Despite this, the Appellate Body has held that a "single divergent opinion is not reasonably sufficient to overturn the contrary conclusions reached in the scientific studies", particularly if those other studies are more specific. ${ }^{110}$ This finding augments SA's argument because there are numerous pest-risk assessments conducted by inter alia, Kotze, Hattingh et al and Paul et al, that contradict the divergent opinion of the EU. Thus, the divergent opinion of the EFSA needs to be specific and supported by some evidence as well. ${ }^{111}$ SA's CBS Expert Panel of 2014 believes that the EFSA PRA of 2014 is devoid of reliable evidence to support the alternative view. ${ }^{112}$

Consequently, there is clearly no scientific basis for the CDI 2000 and CID 2014, and even in instances which purport to lay a foundation for scientific proof, the evidence is simply a single divergent scientific opinion which has been repeatedly supplanted by more specific studies, while such divergent opinion is supported by little or unreliable evidence. Osiemo submits that protectionist intent may be discerned where a country's measures are arbitrary and unsupported by scientific evidence.

In tandem with Article 2.1 of SPS, Article 5.1 of the SPS requires due consideration. Article 5.1 of the SPS provides that WTO members must conduct a risk assessment, and base the SPS measure they finally select upon that risk assessment. The SA CBS PRA 2000 on the export of fresh

105 Panel Report US-Certain measures affecting imports of poultry from China WT/DS392/R par 7.181.

106 Smyth et al 201112 J World Investment \& Trade 13.

107 Ibid.

108 CBS Expert Panel 2014 August 2014 http://www.citrusres.com (accessed 2016-03-26) 6.

109 Panel Report US-Certain measures affecting imports of poultry from China WT/DS392/R par 7.181.

110 CBS Expert Panel 2014 August 2014 http://www.citrusres.com (accessed 2016-22-07) 6.

111 Gruszczynski "Science in the Process of Risk Regulation under the WTO Agreement on Sanitary and Phytosanitary Measures" 20087 German LJ 371388.

112 CBS Expert Panel 2014 August 2014 http://www.citrusres.com (accessed 2016-22-07) 6.

113 Osiemo "The last frontier: Sanitary and Phytosanitary standards and technical regulations as Non-Tariff barriers in intra-African trade" 2015 23(1) African Journal of International and Comparative Law 174192. 
citrus fruit from CBS-infected production regions in SA to the EU concluded that it is abundantly clear that the risk of CBS to European citrus-producing countries is non-existent. ${ }^{114}$ This finding is also shared by Paul et al who concluded that the climate of EU countries is unsuitable for establishment of the CBS disease-causing organism. ${ }^{115}$ Paul et al also found that CBS is unable to establish nor persist in Europe. ${ }^{116}$ This is contrary to the findings of the EFSA PRA of 2008, which concluded that the probability of CBS establishing in the PRA area is greater than that indicated in the South Africa CBS PRA of $2000 .{ }^{17}$ However, recently, the EFSA PRA of 2014 concluded that the probability of entry via the citrus-fruit pathway, establishment and spread of CBS in the EU is rated as moderately likely with little knowledge on how CBS will respond to the EU climate. ${ }^{118}$ This implies that the risk of CBS establishment is low and that the EU has limited knowledge on CBS, and has based its SPS regime on speculation rather than science.

It must be noted though that the EU has questioned Paul et al's CLIMEX model on the basis that it does not take into account any biological information of the pest, and that the selection of the stations whose climate is suitable to CBS in SA, appears to have excluded the Eastern Cape where CBS is also present. ${ }^{19}$ The aim of the CLIMEX model is to describe the core responses of a species to climate, by providing a single number to indicate the climatic favourability of a location for a specific species. ${ }^{120}$ Thus the model is based on the assumption that organisms are efficient integrators of climate and other environmental variables.

However, the criticism of the CLIMEX model was discounted by Hattingh et al who developed a new CLIMEX model to appropriately describe the current distribution of CBS, as well as its potential distribution worldwide. ${ }^{122}$ The new CLIMEX model (Hattingh et al) indicates that, whilst there is the potential for infection events to occur, it is highly unlikely that this pathogen could establish in Europe. ${ }^{123}$ Therefore, based on the abovementioned, it is clear that the current SPS measures lack a sufficient scientific basis in violation of the requirements of Articles 2.2 and 5.1 of the SPS agreement.

Significantly, the IPPC explicitly provided that the spread of CBS to new areas such as the EU is assumed to have taken place through infected

114 Hattingh et al "Pest Risk Assessment document for the review of current phytosanitary regulations pertaining to the export of fresh Citrus fruit from the Republic of South Africa to the EU" May $2000 \mathrm{http}: / /$ www.citrusres.com/ 13.

115 Paul et al "The potential global geographical distribution of Citrus Black Spot caused by Guignardia citricarpa (Kiely): likelihood of disease establishment in the European Union" 200524 Crop Protection 297306.

116 Ibid.

117 EFSA "Pest risk assessment made by South Africa on Guignardia citricarpa Kiely: Scientific Opinion of the Panel on Plant Health (Question No EFSA-Q-2008-299) Adopted on 17 December" 2008925 EFSA Journal 84-108.

118 EFSA 2014 EFSA Journal 173-174.

119 EFSA 2008 EFSA Journal 17-108.

120 Paul et al 2005 Crop Protection 298.

121 Ibid.

122 Hattingh et al "CLIMEX Analysis of the Potential Distribution of Guignardia citricarpa and the Risk Posed to Europe" 201344 Crop Protection 18 23-27.

123 Hattingh et al 2013 Crop Protection 25. 
nursery stock, or other planting material, rather than through citrus fruit. ${ }^{124}$ Secondly, the IPPC provides that CBS has not been reported from Europe. ${ }^{125}$ Thus the spread of CBS through imports to the EU is highly unlikely. It follows therefore that the EU SPS regime contravenes Article 3.1 of the SPS since it is not in line with an international standard. This is because the IPPC is recognized as an international standard in the Preamble to the SPS and in Annex 1(3)(c), which provides for international standards, guidelines and recommendations for plant health, the international standards, guidelines and recommendations developed under the auspices of the Secretariat of the International Plant Protection Convention.

In the alternative, the EU could argue that their SPS measures in CDI 2000 and CID 2014 are valid on the basis of the precautionary principle. The precautionary principle entails that where there are threats of serious or irreversible damage lack of full scientific certainty shall not be used as a reason for postponing cost-effective measures to prevent environmental degradation. ${ }^{126}$ Thus the precautionary principle requires countries to err on the side of caution. It is regarded by some as a general principle of customary international environmental law. ${ }^{127}$ Thus lack of scientific certainty to justify the EU SPS measures could be alleviated through the precautionary principle. This is because, the $A B$ in EC-Hormones left the door ajar for the precautionary principle to act as a ground justification in instances where "responsible, representative governments commonly act from perspectives of prudence and precaution where risks of irreversible, for instance in life-terminating, damage to human health are concerned". ${ }^{128}$

However, in the same judgment, the $A B$ in EC-Hormones held that precautionary principle is not regarded as a ground of justification for an SPS measure in the SPS agreement, and does not override the provisions of Articles 5.1 and 5.2 of the SPS agreement. ${ }^{129}$ Secondly, this ground should not be available because the basic premise of the SPS agreement is that SPS measures must be supported by scientific evidence. ${ }^{130}$ Lastly, this ground of justification should not be available to the EU as the prevailing scientific opinion is that CBS is harmless to human beings.

$A$ radical yet cogent argument has been developed by the EU in ECHormones case. The EU could simply argue that public perceptions of

124 IPPC "ISPM 27 Diagnostic protocols for regulated pests DP 5: Phyllosticta citricarpa (McAlpine) Aa on fruit" 29 August $2014 \mathrm{http}: / / w w w . f a o . o r g / 3 / a-m l 513 e . p d f$ DP5-3.

125 IPPC 29 August 2014 http://www.fao.org/3/a-ml513e.pdf DP5-2.

126 Principle 15 of the Rio Declaration on Environment and Development 1992.

127 Appellate Body Report, EC - Measures concerning meat and meat products (Hormones) par 123.

128 Appellate Body Report, EC - Measures concerning meat and meat products (Hormones) par 124.

129 Appellate Body, Report, EC - Measures concerning meat and meat products (Hormones) par 124-125.

130 Foster "Japan - Measures Affecting the Importation of Apples: Rotten to the Core?" 25 Australian Year Book of International Law 320. 
particular risks may serve as a justification for the CDI 2000. ${ }^{131}$ A perceived risk needs to be genuine, otherwise it would fail the test of a scientific basis as provided in Article 2.2 and 5.1, and there are no compelling reasons against such an approach. ${ }^{132}$ In accordance with Article 5.5, an appropriate level of protection (ALOP) itself reflects the preferences of a particular society for the level of risk exposure, and the differences in these preferences should be relevant in the context of the SPS Agreement. ${ }^{133}$ This is particularly significant because, by its very nature, CBS causes unsightly superficial lesions on fruits that may discourage the public from buying citrus produce. This would obviously lead to huge financial losses for EU producers. Thus public perception requires due consideration on a case-bycase basis, with the added requirement that the public perception on the risk has to be reasonable and connected to public-health concerns and the protection of human life. It must be borne in mind that CBS poses no health threat to humans and thus this ground of justification would likely fail.

Ultimately, the $A B$ has noted that Article 2.2 requires that there be a rational or objective relationship between the SPS measure and the scientific evidence. ${ }^{134} \mathrm{~A}$ finding that there is no scientific basis for a SPS measure as has been established above, invariably means that there is no rational connection between the said measure and the PRA.

\section{Ground 2: That there is no rational connection between the SPS measure and PRA}

According to Article 2.2, a panel must determine whether the results of the risk assessment sufficiently warrant the challenged SPS measures. ${ }^{135}$ That is to say, there must be a "rational or objective relationship" between the SPS measures and the scientific assessment. ${ }^{136}$ In this regard, the South Africa CBS PRA of 2000, which was further expanded through several bilateral exchanges between South African and EU CBS working groups over the period 2001 to 2009 (SA CBS PRA 2000-2009) and ${ }^{137}$ the United States of America, have both similarly concluded that the fresh citrus fruit pathway does not represent an epidemiologically significant pathway for the entry, establishment and spread of $P$. citricarpa. ${ }^{138}$ Significantly, the EFSA PRA 2014 on CBS conceded that, despite recent studies, there are still

131 Gruszczynski "Risk-management policies under the WTO agreement bon the application of sanitary and phytosanitary measurers" 20083 Asian J WTO \& Int'l Health L \& Pol'y 261 281.

132 Gruszczynski 20083 Asian J WTO \& Int'l Health L \& Pol'y 282.

133 Ibid.

134 Appellate Body Report, Japan - Measures affecting Agricultural Products WT/DS76/AB/R par 74-80.

135 Australia Apples par 215.

136 Ibid.

137 CBS Expert Panel 2014 August 2014 http://www.citrusres.com (accessed 2016-24-06) 2.

138 Ibid. See also USDA "USDA Risk assessment of Citrus spp. fruit as a pathway for the introduction of Guignardia citricarpa Kiely, the organism that causes Citrus Black Spot disease December 9, 2010" www.aphis.usda.gov (accessed 2016-07-22) 28. 
various sources of uncertainty related to the citrus fruit pathway and the probability of CBS establishing and causing impacts in the EU. ${ }^{139}$

Furthermore, the SA CBS Expert Panel of 2014 contends that the EFSA PRA 2014 on CBS is based on scientifically weak evidence and untested assumptions, inappropriate test conditions, untested hypothetical reasoning and based on erroneous information. ${ }^{140}$ The SA CBS Expert Panel of 2014 further contends that the EFSA's assessment of the available scientific evidence and familiarity with the CBS disease supports the conclusions of earlier CBS PRAs that fresh fruit does not pose a risk as a potential pathway for the entry, establishment and spread of CBS in the European Union. ${ }^{14}$ This is validated by Paul et al who found that, based on climatic conditions, the likelihood and probability of CBS establishing itself in a region with climatic conditions such as those in Europe are highly unlikely, and even in the highly unlikely event that infection were to take place, it would struggle to persist. ${ }^{142}$ In the same vein, Kotze questions why CBS has never established in the Mediterranean climate of the Western Cape in South Africa. ${ }^{143}$ Kotze submits that the fact that CBS does not occur under Mediterranean climatic conditions outweighs all hypothetical speculations about possible splash infections during rain and whatever is supposed to follow. ${ }^{144}$ What is more, Hattingh et al has also found that, based on best available climatic data, it is highly unlikely that CBS could establish in Europe although he does concede that there is potential for infection events to occur. ${ }^{145}$ Further strengthening SA's case are Fourie et al, who submit that for CBS to establish in Europe, it would have to behave like it had never before in any part of the world. ${ }^{146}$ It is clear that even in countries where CBS is present, some areas still remain CBS free because some citrus-producing regions in South Africa, namely the Northern Cape and the Western Cape, are free of CBS, this despite centuries of the movement of CBS-infected citrus and nursery trees in to these regions. ${ }^{147}$ Consequently, SA contends that, on the back of all the PRAs conducted by all international experts, who have all concluded that since citrus production in Europe only occurs in Southern European countries with a Mediterranean climate, the likelihood of spread and establishment of CBS in Europe is minimal and without justification. ${ }^{14}$

139 EFSA "Statement on the comments by Hattingh et al (2014) on the EFSA PLH Panel (2014) Scientific Opinion on Citrus Black Spot" 2015 13(1) EFSA Journal 39906.

140 CBS Expert Panel 2014 August 2014 http://www.citrusres.com 3.

141 CBS Expert Panel 2014 August 2014 http://www.citrusres.com 7.

142 Paul et al 2005 Crop Protection 94.

143 Kotze "Comments on: EFSA (2008) Scientific Opinion of the Panel on Plant Health on a request from the European Commission on Guignardia citricarpa Kiely" May 2009 http://www.citrusres.com/3.

144 Kotze May 2009 http://www.citrusres.com/ (accessed 2016-03-23) 6.

145 Hattingh et al 2013 Crop Protection 25-27.

146 Fourie et al "Report: Rainfall and temperature comparison of citrus producing areas with known presence or absence of Guignardia citricarpa" September 2009 http://www.citrusres.com/ (accessed 2016-06-23) 5.

147 Hattingh et al "Citrus Black Spot: for the review of current phytosanitary regulations pertaining to the export of fresh Citrus fruit from the Republic of South Africa to the EU" May $2000 \mathrm{http}: / /$ www.citrusres.com (accessed 2016-04-23) 13.

148 Hattingh et al May 2000 http://www.citrusres.com (accessed 2016-04-23) 13-16. 
However, it must be noted that the EU has challenged findings on climate being a determinative factor in the establishment of CBS in the EU, and questioned South Africa's classification of what constitutes a "Mediterranean climate". ${ }^{149}$ The EU possesses compelling evidence that the remedial measures employed by SA have not properly dealt with CBS as the EU has recently made 15 detections in 2015 . $^{150}$ Living stages of CBS are frequently found on imported citrus fruit during border inspections of the EU. ${ }^{151}$

It is trite law that any measure that contradicts the conclusions of a PRA cannot be said to be based upon it. ${ }^{152}$ Thus it is clear that the weight of scientific opinion is overwhelmingly on the side of South Africa that the EU SPS measures have no rational connection to the results of the various PRAs conducted by South African and international experts; the governments of South Africa, the European Union itself and the United States of America. On this ground alone, the CDI 2000 and CID 2014 stand to fail.

Consequently, the EU SPS regime on SA citrus produce would also fall foul of Article 5.3 of the SPS, which defines a PRA as the evaluation of the likelihood of entry, establishment or spread of a pest or disease within the territory of an importing member according to the sanitary or phytosanitary measures which might be applied, and of the associated potentially biological and economic consequences. This was affirmed in the Panel Report Australia - Measures Affecting the importation of Salmon case. ${ }^{153}$ It is clear from the aforementioned that the EU has failed to establish the likelihood of entry, establishment and spread of CBS in Europe.

\section{Ground 3: That the SPS measures constitute disguised discrimination}

The Appellate Body has clarified that Article 2.3 of the SPS Agreement contains two primary obligations: ${ }^{154}$ The first obligation is contained in the first sentence: "Members shall ensure that their sanitary and phytosanitary measures do not arbitrarily or unjustifiably discriminate between Members where identical or similar conditions prevail." ${ }^{155}$ The second obligation is contained in the second sentence: "Sanitary and phytosanitary measures shall not be applied in a manner which would constitute a disguised

149 European Commission: Health and Consumer Protection Directorate - General "Report of the Working Group on evaluation on the Pest Risk Assessment prepared by South African Citrus Black Spot" 2.

150 Du Preez "Organic Citrus Farmers Voluntarily Halt Lemon Exports to the EU" 22 April 2016 Farmer's Weekly.

151 EFSA Panel on Plant Health (PLH) "Scientific Opinion on the risk of Phyllosticta citricarpa (Guignardia Citricarpa) for the EU territory with identification and evaluation of risk reduction options" 2014 12(2) EFSA Journal 355732.

152 Report of the Panel United States - Measures affecting the importation of animals, meat and other animal products from Argentina (US Argentina Meat) par 7.324.

153 Australia Salmon par 121-123.

154 Australia Salmon par 252. See also Panel Report India - Measures concerning the importation of certain Agricultural Products WT/DS430/R par 7.388.

155 Panel Report United States - Measures affecting the importation of animals, meat and other animal products from WT/DS447/R par 7.550 . 
restriction on international trade." ${ }^{156}$ The focus of this article is on the second sentence, the absence of scientific evidence implies that the EU SPS measures are discriminatory. This entails consideration of the chapeau of Article $\mathrm{XX}(\mathrm{b})$ of the GATT. This is because the SPS elaborates and thus explains the provisions of Article $\mathrm{XX}(\mathrm{b})$ in further detail when dealing with SPS measures.

Furthermore, a finding that a measure results in arbitrary or unjustifiable discrimination necessarily entails a finding that it constitutes a disguised restriction on international trade. ${ }^{158}$ Since it has been established in this article that there is no scientific basis for the EU SPS measures, and that no rational relationship exists between the EU SPS measures and the PRAs conducted, this invariably implies that the EU SPS measures are arbitrary and constitute disguised discrimination. South Africa may argue that the tighter restrictions and threat of a ban by Europe is a measure aimed at disguised discrimination intended to impede market access to countries from outside the EU. The SA CBS PRA of 2000 contends that the current SPS measures are inappropriately restrictive and must be rescinded. ${ }^{159}$ Van den Bossche asserts that some countries use so-called SPS measures as instruments of trade protection. ${ }^{160}$ This contention is supported by South Africa who contends that the EU are using SPS measures as a protectionist measure to block imports, because there is no scientific basis for its claim that CBS could infect European orchards. ${ }^{161}$ This viewpoint is also shared by Smyth et al who contend that since countries are allowed to set their accepted level of protection, countries can set it at zero which makes it impossible for other countries to comply with, and festers protectionism. ${ }^{162}$ The EU disputes this allegation and submits that EU citrus producers and South African citrus exporters are in effect not in competition as their dissimilar growing seasons complement one another, and that the EU's citrus-producing countries need imports during their off-season as they aim to ensure that commercial and distribution chains remain in place throughout the year. ${ }^{163}$

\section{Ground 4: That the SPS measures do not have the objective of minimizing trade effects}

Gebrehiwet et al have concluded that that stringent SPS standards set by developed countries have a potential to offset the perceived gain of

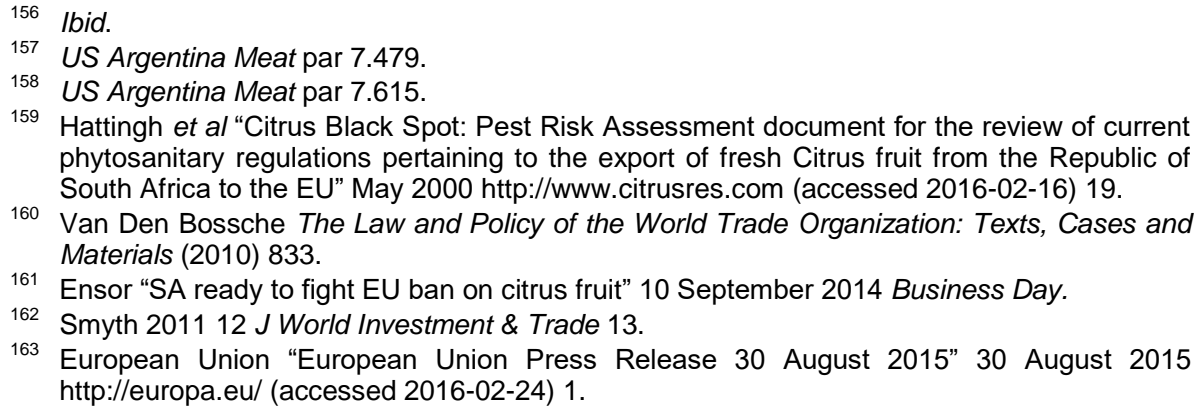

163 European Union "European Union Press Release 30 August 2015" 30 August 2015 http://europa.eu/ (accessed 2016-02-24) 1. 
liberalizing agricultural trade. ${ }^{164}$ To combat this, Article 5.4 of the SPS requires that members must take into account the objective of minimizing negative trade effects when determining the appropriate level of an SPS measure. Article 5.4 must be read with Article 5.6 of the SPS which essentially provides that members shall ensure that such measures are not more trade-restrictive than required to achieve their appropriate level of sanitary or phytosanitary protection, taking into account technical and economic feasibility. The $A B$ has found that the obligation in Article 5.6 is closely related to the first obligation set forth in Article 2.2, that members shall ensure that any SPS measure is applied only to the extent necessary to protect human, animal or plant life or health.

Bearing in mind the fact that CBS is not harmful to humans and only causes superficial lesions, it is clear that the CDI 2000 and the CID 2014 go beyond what is necessary to preserve human life, and will lead to the loss of 80000 jobs in SA. ${ }^{166}$ Furthermore, South Africa is expected to lose about ten to fifteen percent of its exports to the EU, and the CGA submits that SA has spent over 1 billion in a bid to comply with the onerous provisions of the SPS measures created by CDI 2000 and CID 2014. ${ }^{167}$ Thirdly, South Africa projects that, if the EU closed its market to SA citrus, the local economy would not only lose almost R26 bn, many of the 84500 on-farm jobs and 40 000 up- and down-stream jobs that the industry provides would be at risk. ${ }^{168}$ Consequently, it is clear that the CDI 2000 does not seek to minimize trade effects.

However, the Panel in United States - Measures affecting the importation of animals, meat and other animal products from Argentina concludes that the use of the word "should" in Article 5.4 cannot be read as imposing an affirmative obligation on WTO Members such that they must or shall take into account the objective of minimizing negative trade effects when determining their appropriate level of protection. ${ }^{169}$ Thus, the adoption of the least trade-restrictive ALOP is not required by Article 5.4. ${ }^{170}$

\section{Ground 5: That the SPS measures are more trade- restrictive than necessary}

Article 5.6 of the SPS essentially provides that SPS measures are not more trade-restrictive than required to achieve their appropriate level of sanitary or phytosanitary protection, taking into account technical and economic feasibility. In Australia - Measures affecting importation of salmon, the AB confirmed the reasoning that footnote 3 to Article 5.6 provides a three-

\footnotetext{
164 Gebrehiwet et al "Quantifying the Trade Effect of Sanitary and Phytosanitary Regulations of OECD Countries on South African Food Exports" 2001 46(1) Agrekon 2336.

165 US Argentina Meat par 7.367.

166 Farmer's Weekly "EU bans SA citrus for the rest of the year" 29 November 2013 Farmer's Weekly.

167 CGA “CGA Annual Report 2015" (undated) www.cga.o.za (accessed 2016-04-24) 4.

168 Troye "EU Trade: Time to chuck naartjies" 18 September 2014 Financial Mail.

169 US Argentina Meat par 7.404.

170 US Argentina Meat par 7.408.
} 
pronged test to establish a violation of Article $5.6:^{171}$ The three elements of this test under Article 5.6 are that there is an SPS measure which: firstly, is reasonably available taking into account technical and economic feasibility; secondly, achieves the member's appropriate level of sanitary or phytosanitary protection; and lastly, is significantly less restrictive to trade than the SPS measure contested.

In the AB's view, the abovementioned elements "are cumulative in the sense that, to establish inconsistency with Article 5.6, all of them have to be met". ${ }^{173}$ Therefore, if any of these elements is not fulfilled, the measure in dispute would be consistent with Article 5.6. ${ }^{174}$ The function of Article 5.6 is to ensure that SPS measures are not more trade-restrictive than necessary to achieve a member's appropriate level of protection. ${ }^{175}$ Article 5.6 requires the panel itself to objectively assess, inter alia, whether the alternative measure proposed by the complainant would achieve the importing member's appropriate level of protection. ${ }^{17}$

In the AB's view, such an assessment is to be conducted on the basis of the scientific evidence on the record. ${ }^{177}$ In order to assess whether a less trade-restrictive alternative measure would meet an importing member's ALOP, a panel must make a number of "factual findings". ${ }^{178}$ Specifically, the panel must identify both the level of protection that the importing member has set as its appropriate level, and the level of protection that would be achieved by the alternative measure put forth by the complainant. ${ }^{179}$ Thereupon the panel will be able to make the requisite comparison between the level of protection that would be achieved by the alternative measure and the importing member's appropriate level of protection. ${ }^{180}$ If the level of protection achieved by the proposed alternative meets or exceeds the appropriate level of protection, then, assuming that the other two conditions in Article 5.6 are met, the importing member's SPS measure is more trade restrictive than necessary to achieve its desired level of protection.

The burden rests on the SA as the complaining party to demonstrate a prima facie case that there is an alternative measure that meets all three requirements in Article 5.6. ${ }^{181} \mathrm{~A}$ demonstration that an alternative measure meets the relevant member's appropriate level of protection, is reasonably available, and is significantly less trade-restrictive than the existing measure, suffices to prove that the measure at issue is more trade-restrictive than necessary. ${ }^{182}$ On the basis of the arguments offered above, to the effect that

171 Appellate Body Report, Australia Measures affecting importation of salmon WT/DS18/AB/R par 194.

172 US Argentina Meat par 7.430. See Australia Apples par 360.

173 Appellate Body Report, Australia Measures affecting importation of salmon WT/DS18/AB/R par 194.

174 lbid.

175 Australia Apples par 363.

176 US Argentina Meat par 7.437.

177 Ibid.

18 Australia Apples par 368.

179 Australia Apples par 344.

80 Australia Apples par 356.

81 US Argentina Meat par 7.430. See also Australia Apples par 360.

82 Australia Apples par 363. 
the EU measures lack a sufficient scientific basis, it is clear that the EU SPS regime is unduly restrictive and represents an unnecessarily stringent level of protection against what is a non-existent risk of CBS establishment in the EU. The EU should be satisfied with an SPS certificate from the DAFF in SA, verifying non-existence of CBS in an SA consignment, without the onerous requirements of field inspection nor the stringent traceability-checks and tested-samples requirements. This avenue should be available to SA because the CGA has recently suspended the export of organic lemons to the EU for the 2016 season.

\section{Ground 6: That the SPS measure is applied beyond the extent necessary to protect human, animal or plant life or health}

As a rider to the discussion on Article 5.6, it is necessary to discuss Article 3.2 which is a specific application of the Article 2.2. This ground could have been examined under the grounds of Article 2.2 of the SPS earlier in the discussion, but is raised after the assessment of Article 5.6 of the SPS, on the basis that a violation of the latter means a violation of the former.

Article 3.2 of the SPS provides the rebuttable presumption that SPS measures that conform to international standards, guidelines or recommendations, are necessary to protect human, animal or plant life or health, and are consistent with the relevant provisions of this Agreement and of GATT 1994. ${ }^{183}$ This implies that an SPS measure that is not in line with international standards or recommendations is not necessary to protect human life. Thus a violation of Article 3.2 consequentially implies a violation of the corresponding obligation in Article 2.2 of the SPS .This is because the $A B$ had held that the basic obligations set out in Article 2 of the SPS inform, impart meaning to, and are made operative in other provisions of the SPS. Article 3.2 is an explanation of the basic rights created in Article 2.2 which requires that a member's SPS measures be applied to the extent necessary to protect human, animal or plant life or health. Therefore, having established that the EUS SPS regime is not in line with international standards, one could conceivably argue that the measures are not necessary to protect human life.

Further to this point, the $A B$ has endorsed the close link between Article 2.2 and Article 5.6 of the SPS. ${ }^{184}$ Thus, the AB in India-Measures concerning the importation of certain agricultural products has endorsed the Panel Report's ratio that a violation of Article 5.6 consequentially means a violation of Article 2.2 of the SPS. ${ }^{185}$ Consequently, if SA can prove as established above that an alternative regime is available, it would immediately mean that the EU SPS regime violates Article 2.2 in this regard, and that the measures

183 Article 3.2 of the SPS .See Appellate Body Report, United States -Continued suspension of obligations in the EC-Hormones dispute WT/DS321/AB/R par 532.

184 Appellate Body Report, India-Measures concerning the importation of certain agricultural products WT/DS430/AB/R par 5.208. See Australia Apples par 340.

185 Appellate Body Report, India-Measures concerning the importation of certain agricultural products WT/DS430/AB/R par 5.208. 
are not applied to the extent necessary to protect human, animal or plant life or health.

\section{Ground 7: That the SPS measures do not take into account special needs of developing countries}

The preamble of the SPS enjoins the developed contracting parties to be considerate towards the developing country members, and assist them in their attempts to comply with SPS measures to enhance their market access. Article 10.1 of the SPS in the same vein essentially provides states that members shall take account of the special needs of developing country members. The burden of proof in Article 10.1 begins with a determination of whether a specific special need of a developing country member has been identified. ${ }^{186}$ South Africa is a developing country, and as such all export markets are invaluable, and the loss of an export market the size of the EU would have catastrophic consequences for South Africa. This is validated by the South Africa CBS PRA 2000 which submitted that the EU SPS measures are likely to impact approximately half a million people reliant on the industry. ${ }^{87}$ However, the Panel in EC - Approval and Marketing of Biotech Products found that Article 10.1 does not provide that the importing Member must invariably accord special and differential treatment in a case where a measure has led, or may lead, to a decrease, or a slower increase, in developing country exports. ${ }^{188}$

\section{$5 \quad$ CONCLUSION}

The objective of this article was to suggest the legal grounds for a challenge of the SPS measures employed by the European Union. The first legal issue that is investigated is whether the EU SPS measures are supported by legitimate science. It is found that, even though the EFSA is a reputable science institution, the science employed has been questioned by South Africa and various international pest-risk assessments.

Secondly, the question was posed whether there is scientific basis for the EU SPS regime and the attendant legal issue of whether there is a rational link between the EU SPS regime and the science informing it. It is found through a careful study of the various PRAs conducted by South Africa, the United States of America and various international experts, as well as the Appellate Body Reports of the WTO, that the EU SPS regime lacks a scientific basis and lacks a causal nexus with the relevant scientific findings.

Thirdly, it was discussed whether the measures are aimed at disguised discrimination. It is found through a study of the SA PRAs that the EU SPS regime has a semblance of protectionist intent. The fourth legal issue that

86 US Argentina Meat par 7.688.

187 Hattingh et al "Citrus Black Spot: Pest Risk Assessment document for the review of current phytosanitary regulations pertaining to the export of fresh citrus fruit from the Republic of South Africa to the EU" May 2000 www.citrusres.com (accessed 2016-08-01) 2.

188 Panel Report European Communities - Measures affecting the approval and marketing of biotech products WT/DS291/R; WT/DS292/R; WT/DS293/R par 7.1620. See US Argentina Meat par 7.703. 
emanates is whether the EU SPS regime seeks to minimize trade effects. In this regard, through a studious review of Appellate Body Reports, it is found that the SPS does not place an affirmative obligation on the EU to minimize trade effects.

Fifthly, there was an assessment of whether the EU SPS-measures are necessary to preserve human and plant life. It is found through a study of the AB Reports and the EU SPS regime that the EU SPS regime goes beyond what is necessary to preserve human and plant life. Furthermore, on the ground of whether the measures are not more trade-restrictive than necessary, it is found through the lens of the AB Reports and a study of the SA DAFF phytosanitary and sanitary regime that the EU SPS regime is unduly trade-restrictive.

The final legal issue is whether the EU SPS regime does not take into account the special needs of developing countries. The SA PRAs and the CGA in its annual reports have reiterated the notion that the EU SPS regime disregards the special needs of the SA economy. However, the $A B$ has intimated that the EU need not consider the special needs of South Africa in instances whereby its SPS regime leads to a decrease or slower increase in developing-country exports.

It is clear from the PRAs discussed in this article, in accordance with the requirements of the relevant Articles of the SPS, that the likelihood of CBS establishing itself and spreading in the EU is miniscule. As such, it is fairly reasonable to assume that in the event that South Africa would bring the matter before the WTO for adjudication, the panel would find in favour of South Africa, as the EU lacks the scientific justification and has failed to establish a rational connection between the SPS measures employed and the numerous PRAs conducted. The EU SPS regime is neither based on sufficient scientific evidence nor scientific certainty; rather, it is based on speculation and conjecture, both of which are never grounds for establishing an appropriate level of protection. 